\title{
UM OLHAR PARA A VIDA E OBRA DE LUZIMAR TELLES E SUA CONTRIBUIÇÃO PARA A ARQUITETURA MODERNA DE CATAGUASES
}

\section{A LOOK AT THE LIFE AND WORK OF LUZIMAR TELLES AND ITS CONTRIBUTION TO THE MODERN ARCHITECTURE OF CATAGUASES}

\author{
Filipe Quaresma Poyares de Oliveira ${ }^{1}$ \\ Universidade Federal de Viçosa, Viçosa, MG, Brasil, filipeqpo@gmail.com \\ Denise Mônaco dos Santos ${ }^{2}$ \\ Universidade Federal de Viçosa, Viçosa, MG, Brasil, denise.monaco@ufv.br
}

\begin{abstract}
Resumo
O artigo apresenta e discute a biografia do arquiteto Luzimar Telles, até então inexplorada, destacando sua formação e trajetória profissional em Cataguases, onde radicou-se. A cidade, por sua vez, destaca-se no contexto da historiografia da arquitetura moderna brasileira por seu significativo patrimônio. Relata o método de pesquisa empregado durante a etapa de pesquisa biográfica, parte integrante de uma investigação maior que analisou vinte e oito obras residenciais do arquiteto. Tal metodologia foi centrada principalmente em levantamento documental em acervos públicos e privados de Cataguases e também do Rio de Janeiro, além de entrevistas semiestruturadas com membros remanescentes da família. Neste estudo, que procurou paralelos entre vida e obra de Telles, inferiu-se que o início de sua atuação profissional como arquiteto tem relação com sua habilidade com desenho técnico e começou ainda antes de sua formação acadêmica. Observou-se a atuação de Telles como designer de móveis e a existência de mudança significativa na linguagem arquitetônica adotada pelo arquiteto a partir da década de 1970. A contribuição do trabalho é a de abordar pela primeira vez, de modo sistematizado, a trajetória profissional deste arquiteto, apontado como autor do maior número de obras modernas em Cataguases. Como resultados, obteve-se um aprofundamento acerca da trajetória profissional de Luzimar Telles e sua atuação em Cataguases. O tempo de atividade profissional de Telles e a lista de seus projetos na cidade foi significativamente ampliada, estabelecendo, assim, bases referenciais mais precisas para a continuidade de investigações acerca de sua produção.
\end{abstract}

Palavras-chave: Arquitetura moderna brasileira. Luzimar Telles. Cataguases. Pesquisa documental.

\begin{abstract}
The article presents and discusses the biography of the architect Luzimar Telles, hitherto unexplored, highlighting his education and professional trajectory in Cataguases, where he settled. In its turn, the city stands out in the context of the historiography of modern Brazilian architecture for its significant heritage. It reports the research method used during the biographical research stage, part of a larger investigation that analyzed twenty-eight residential works by the architect. Such methodology mainly focused on documentary surveys in public and private collections in Cataguases and Rio de Janeiro, in addition to semi-structured interviews with the remaining family members. In this study, which sought parallels between Telles' life and work, it was inferred that the beginning of his professional practice as an architect has to do with his technical drawing skills and started even before his academic training. Telles was observed as a furniture designer and the existence of a significant change in his architectural language adopted since the 1970s. This work's contribution is to approach, for the first time, in a systematic way, the professional trajectory of this architect, appointed as the author of the largest number of modern works in Cataguases. As a result, a deepening of Luzimar Telles' professional trajectory and his performance in Cataguases was obtained. Telles' professional activity time and the list of his projects in the city have been significantly extended, thus establishing more precise reference bases for the continuation of investigations about his production.
\end{abstract}

Keywords: Brazilian modern architecture. Luzimar Telles. Cataguases. Documentary research.

How to cite this article:

OLIVEIRA, F. Q. P. DE; SANTOS, D. M. DOS. Um olhar para a vida e obra de Luzimar Telles e sua contribuição para a arquitetura moderna de Cataguases. PARC Pesquisa em Arquitetura e Construção, v. 11, p. e020017, 19 ago. 2020. DOI: https://doi.org/10.20396/parc.v11i0.8657308 


\section{Introdução}

Cataguases, cidade da região da Zona da Mata de Minas Gerais, tem uma forte relação histórica com a arte moderna brasileira. Na primeira metade do século XX, foi palco de experiências culturais de linguagem essencialmente moderna. São exemplos o ciclo cinematográfico de Humberto Mauro (1925 a 1929), a literatura da Revista Verde (1927 a 1929), e o conjunto de obras arquitetônicas construídas a partir de 1940.

Pelas ruas do centro de Cataguases foram edificadas várias obras, entre residências, edifícios institucionais (colégio, igreja, orfanato, maternidade) e edifícios comerciais (escritórios, hotel, cinema), além de praças e monumentos, muitas das quais assinadas por arquitetos de reconhecido destaque nacional ligados ao movimento moderno, como Oscar Niemeyer, Francisco Bolonha, Carlos Leão, Aldary Toledo, Edgard Guimarães do Valle e irmãos Roberto. Muitas dessas obras agregam ainda outros elementos artísticos, dentre os quais merecem destaque projetos paisagísticos de Burle Marx, painéis de Portinari e Djanira, esculturas de Jan Zach e Bruno Giorgi, e mobiliários de Joaquim Tenreiro (ALONSO, 2010). Dada a relevância deste conjunto, o Instituto do Patrimônio Histórico e Artístico Nacional (IPHAN) tombou, em 1994, dezesseis destes imóveis, e, em 2003, estabeleceu uma área de proteção na região central da cidade (FIGURA 1). Cataguases é, assim, um dos 68 conjuntos urbanos brasileiros tombados em âmbito federal'. A cidade está incluída também no mapa do Docomomo International, principal organização mundial de discussão e conservação da arquitetura do Movimento Moderno ${ }^{2}$. Publicações de destaque nacionais e internacionais mencionam a relevância da cidade no cenário do modernismo arquitetônico, como a revista L'Architecture d'Aujourd'hui, que em 1952, em edição dedicada à arquitetura brasileira, publicou o artigo "Audaces D'architecture et d'Art" apresentando alguns dos edifícios modernos de Cataguases (COUTO, 2004). Em publicação sobre a arquitetura moderna brasileira, Cavalcanti (2001) menciona Cataguases juntamente com obras de destaque nacional como Brasília, o conjunto da Pampulha e o edifício do Ministério da Educação e Saúde. Estes, e ainda outros exemplos, atestam a inserção de Cataguases, pequena cidade do interior mineiro, na historiografia da arquitetura moderna nacional e internacional.

Além dos arquitetos renomados, pertencentes à vanguarda da arquitetura moderna brasileira, atuaram também na cidade outros profissionais, por vezes considerados de menor expressão, principalmente frente ao reconhecimento consolidado que seus pares já gozavam naquele momento. Dentre estes, destaca-se Luzimar Natalino Cerqueira de Góes Telles (FIGURA 2), projetista e arquiteto que atuou na cidade a partir de 1950, apontado como autor da maior quantidade de projetos modernos em Cataguases (ALONSO, 2010). Grande parte das obras de autoria de Telles está inserida na região de proteção patrimonial estabelecida pelo IPHAN, muito embora nenhuma delas tenha sido tombada individualmente por esse Instituto. Tal fato fomenta algumas indagações, que delinearam os principais pressupostos da investigação em questão. Embora numericamente relevantes, entende-se que as obras de Luzimar Telles não são qualitativamente significativas frente ao conjunto moderno local? Seria inapropriado esse arquiteto figurar no contexto local ao lado de outros amplamente reconhecidos pela historiografia da arquitetura moderna brasileira? 


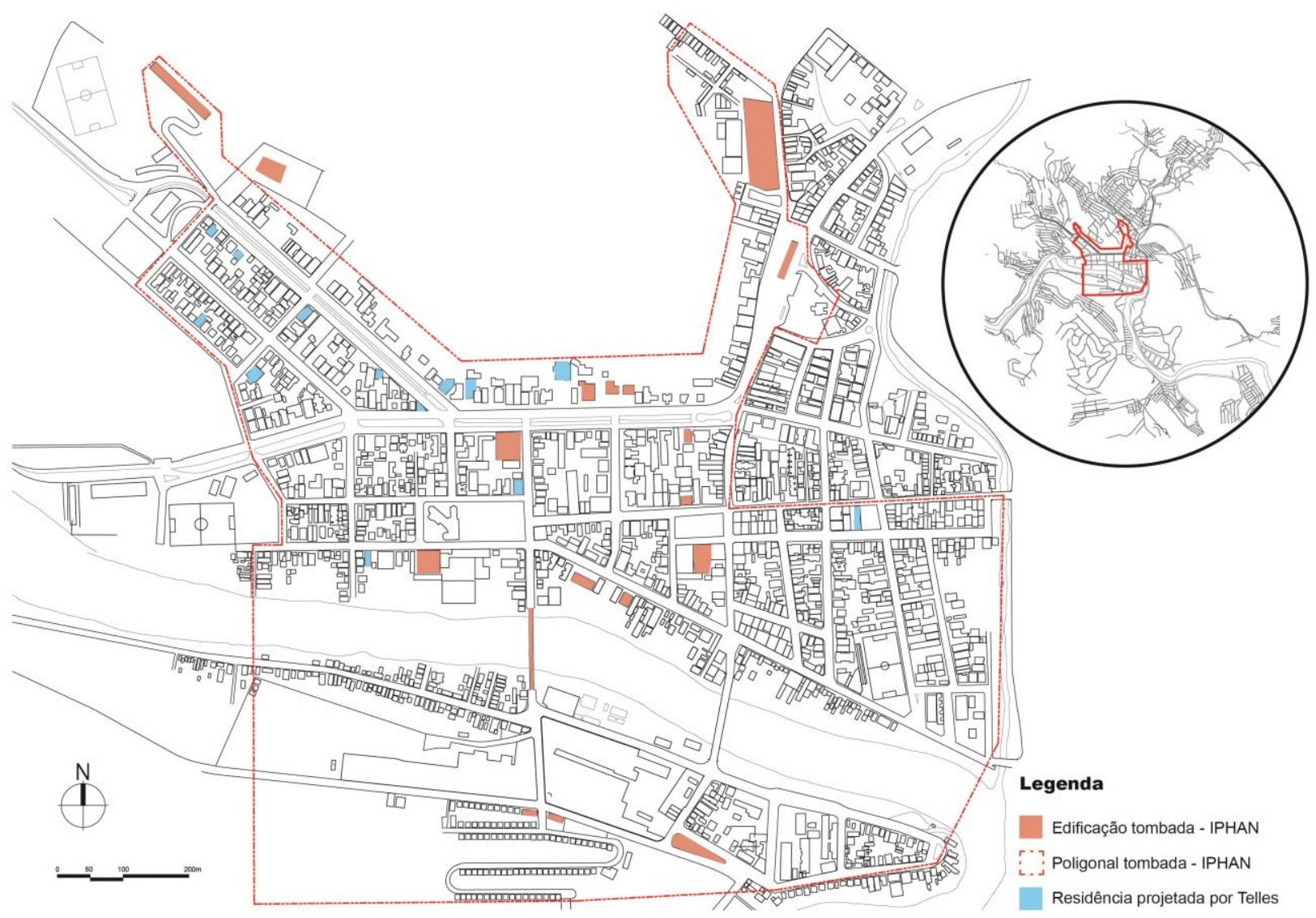

Fonte: Plano Diretor Participativo de Cataguases (2006), adaptado pelos autores.

Enquanto a contribuição de Telles no contexto da arquitetura modernista de Cataguases é citada, ainda que brevemente, em diferentes trabalhos acadêmicos (ALONSO, 2010; LINS, 2012; XAVIER, 2013; MELLO, 2014), sua trajetória profissional, envolvendo formação e práticas projetuais, permanecia inexplorada. Sequer as dimensões quantitativas e qualitativas da sua obra parecem ter sido objeto de investigação mais acurada. Muitos projetos são atribuídos a Luzimar Telles, ainda que, alguns deles, de maneira informal, sem o devido reconhecimento autoral. Edifícios de programas variados: institucionais, comerciais e residenciais, tanto uni quanto multifamiliares, encomendados pela prefeitura e por clientes de diferentes estratos sociais, são, por vezes, apresentados como portadores de exemplar qualidade arquitetônica (ALONSO, 2010; MELLO, 2014), ao mesmo tempo em que outros permanecem na penumbra. Ambos seguem aguardando explorações mais acuradas. Neste sentido, a pesquisa "O Arquiteto Luzimar Telles em Cataguases: um primeiro olhar sobre projetos residenciais, 1950 - 1986" procurou preencher lacunas que se apresentam em torno da obra desse arquiteto, a fim de contribuir com a construção mais consistente da historiografia da arquitetura local, tendo como horizonte ampliar e aprofundar as discussões a respeito do patrimônio arquitetônico de Cataguases. $O$ objetivo foi não só coletar e sistematizar dados referentes a vida e obra de Luzimar Telles, mas sobretudo se debruçar de forma analítica sobre tal obra. Assim, para além do levantamento documental, buscou-se investigar os projetos residenciais do arquiteto, os mais numerosos dentro da sua vasta produção. Para tanto, empregou-se de modo complementar as ferramentas metodológicas de Análise Gráfica segundo 
Clark e Pause (1985), e da Sintaxe Espacial, a partir da teoria proposta por Hillier e Hanson (1984).

Neste artigo, em específico, propõe-se apresentar e discutir resultados dos levantamentos documentais que, ao estabelecer uma ampla contextualização de quem foi Luzimar Telles e qual a amplitude de sua obra, deram suporte aos objetivos de (1) delimitar a relevância de se investigar de forma mais detida seus projetos, e (2) procurar responder qual seria, de fato, a relação de sua produção projetual com o modernismo arquitetônico no contexto de Cataguases.

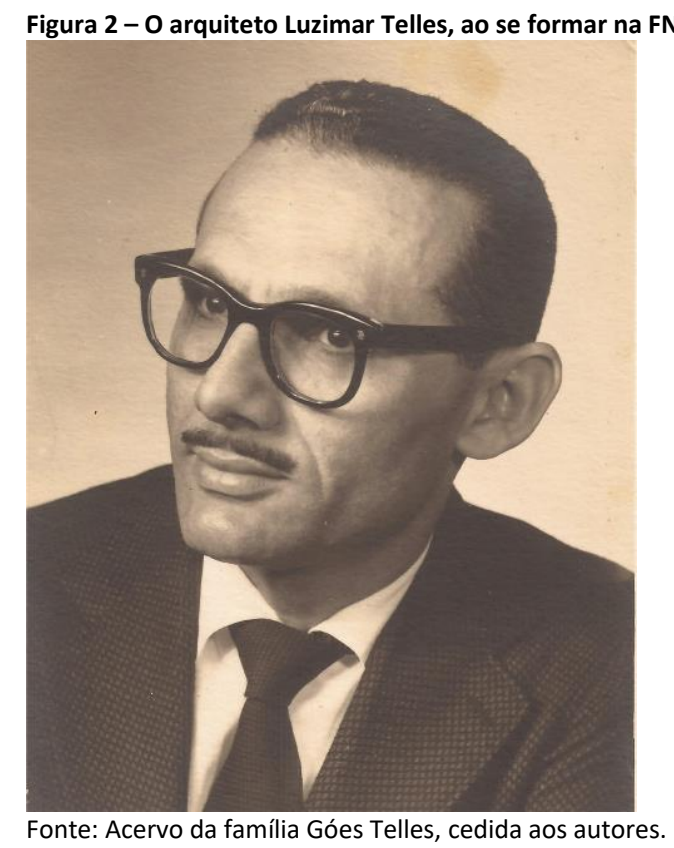

\section{Cataguases: os modernistas consagrados e a "cor local"}

O parecer técnico do arquiteto Antônio Luiz Dias de Andrade, no dossiê de tombamento de Cataguases, indica que o valor da produção da arquitetura moderna da cidade não se limita a assinatura dos projetos:

Restrito o tombamento às obras de arquitetura mais representativas, não há como evitar a redução do sentido e o significado do movimento moderno alcançados na cidade. Há o risco, inclusive, destas obras virem a ser compreendidas como referências significativas no quadro da produção de arquitetos ilustres, autores de seus respectivos projetos, e que têm assegurado lugar de destaque na historiografia da arquitetura moderna no Brasil, dissociando-as, portanto, das peculiares condições em que foram produzidas em Cataguases, e de seus antecedentes (ANDRADE, 1994 apud ALONSO, 2010, p. 61).

Não é sem razão que as abordagens acerca de Cataguases, ainda que explorem diferentes pontos da história local, apresentem especial interesse pela primeira metade do século XX e o singular contexto do modernismo na cidade. A arquitetura figura como um elemento da modernidade local, cujo interesse reside na quantidade e variedade de edificações, somado ainda à presença de trabalhos de arquitetos renomados. As principais referências acadêmicas sobre a arquitetura em Cataguases, mesmo com focos distintos, consideraram necessário mencionar Luzimar Telles. Nestes trabalhos, são apresentados fragmentos da biografia do arquiteto, que pouco conseguem 
contribuir para o entendimento de sua trajetória profissional. Do mesmo modo, projetos de sua autoria são indicados pontualmente.

Mello (2014) afirma que dada a quantidade e qualidade, os projetos de Telles contribuíram para destacar e dar continuidade ao conjunto de arquitetura moderna de Cataguases. O autor considera ainda que, mesmo que mais "simples", estes projetos apresentam "a mesma originalidade na aplicação dos sintagmas corbusianos das demais obras tombadas" (MELLO, 2014, p. 279) e "o mesmo rigor na organização dos espaços internos, na utilização de elementos típicos (...)” (MELLO, 2014, p. 311).

Alonso (2010) questiona aspectos do tombamento de Cataguases, entre os quais, destaca o não tombamento individual de nenhum projeto de Telles. Por sua vez, "Cataguases - arquitetura modernista: guia do patrimônio cultural” (ALONSO, 2009) uma das poucas publicações que sistematiza o acervo local, apresenta um total de vinte e nove projetos considerados relevantes para o conjunto arquitetônico local, sendo dez destes de autoria de Luzimar Telles.

Apesar de considerações positivas e das menções à grande quantidade de projetos de Telles, curiosamente são apresentados os mesmos projetos repetidas vezes. O que justificaria tal recorrência? Seriam estes de fato os exemplares mais significativos produzidos pelo arquiteto? A localização ou o status social dos clientes garantiriam estes destaques? Ou talvez, faltem maiores informações sobre sua produção arquitetônica? Acredita-se que, ao menos, esta última indagação seja verdadeira, como corrobora Lins: "um levantamento preciso de sua obra [Telles] ainda não fora levado a cabo e seria deveras rico" (LINS, 2012, p. 45).

Couto (2004) por sua vez destaca que, em geral, as abordagens acerca de Cataguases destacam a formação do conjunto moderno, apresentando os projetos de forma ampla e descritiva, carecendo de maiores aprofundamentos e análises acerca da arquitetura, o que pode também justificar tal repetição dos projetos de Telles.

Enfatiza-se que a discussão acerca da obra de Telles encontra-se em uma fase inicial, podendo desdobrar-se em diferentes abordagens e recortes acerca de sua trajetória e produção. Nesse sentido, as considerações aqui apresentadas não devem ser aceitas como completas ou definitivas. Em trabalhos desta natureza deve-se ter em mente que "aspectos do autor e da obra sempre permanecerão desconhecidos, velados e inexplicáveis, à espera de futuras interpretações" (MONTANER, 2015, p. 10).

\section{Levantamentos documentais: vida e obra, formação e atuação}

A organização da biografia de Telles e um levantamento de dados acerca de sua produção projetual foram realizados por meio de entrevistas e pesquisas em fontes primárias, como acervos particulares e públicos de Cataguases e Rio de Janeiro. $\mathrm{O}$ objetivo foi investigar e estabelecer paralelos entre sua biografia e produção projetual, buscando estipular suporte contextual para as análises em etapa posterior ${ }^{3}$.

Foram realizadas entrevistas com três filhos do arquiteto, colegas de trabalho e clientes, com objetivo conhecer em detalhes a trajetória de Telles, estabelecer aproximações com sua personalidade, características profissionais e processos de trabalho. Durante a pesquisa, verificou-se que família do arquiteto possui poucos documentos pessoais de Telles e nenhuma cópia de seus projetos, gradativamente perdidos ao longo do tempo.

Desse modo, os levantamentos documentais foram inicialmente guiados por listas existentes - que se mostraram incompletas e com informações imprecisas, e ainda pelas menções em trabalhos acadêmicos, principalmente, no que dizia respeito ao paradeiro dos documentos gráficos ${ }^{4}$. As principais fontes de registros dos projetos do arquiteto 
foram os acervos do Departamento Municipal de Patrimônio Histórico e Artístico de Cataguases (DEMPHAC) e também do Instituto Francisca de Souza Peixoto, ambos em Cataguases.

Após sistematização e cruzamento de informações, obteve-se uma lista de cento e um projetos residenciais produzidos pelo arquiteto, datados de 1950 a 1986. Em um segundo momento, realizou-se a busca pelos documentos gráficos efetivamente arquivados e passíveis de serem analisados, estabelecendo um montante de quarenta e um projetos. Este conjunto balizou os limites temporais da pesquisa, muito embora exista ainda uma significativa quantidade de projetos a ser localizada.

Destaca-se, enquanto resultados do levantamento documental, a ampliação do tempo de atuação de Telles na cidade, cuja referência anterior mencionava o último projeto do arquiteto datado de 1974 (MELLO, 2014), e também da referência em relação a quantidade de obras, anteriormente estimada em sessenta projetos no total (ALONSO, 2010).

O material gráfico levantado é composto por desenhos técnicos: plantas baixas, cortes, elevações e por vezes, detalhamentos. Estes documentos foram registrados, fotografados e posteriormente redesenhados digitalmente de modo a permitir a aplicação das análises em etapas posteriores da pesquisa. Foram ainda sistematizados em fichas de apresentação, que juntamente com a lista final de projetos residenciais, configuram produtos resultantes da pesquisa. Não foi localizado nenhum outro tipo de representação gráfica como croquis ou desenhos processuais do arquiteto. Este pode ser considerado como um limite da investigação: seu processo criativo.

Acerca da formação de Telles como arquiteto, realizou-se levantamento no acervo do Núcleo de Pesquisa Documental (NPD) da Faculdade de Arquitetura e Urbanismo da Universidade Federal do Rio de Janeiro (FAU-UFRJ), que hoje possui o acervo da Faculdade Nacional de Arquitetura (FNA), onde Telles graduou-se. Neste acervo foram levantados diversos documentos do arquiteto, dentre eles o histórico escolar da FNA e também do Colégio Militar do Rio de Janeiro. Não foi localizado, entretanto, nenhum trabalho acadêmico do então estudante. Este aspecto pode ser considerado como outro limite da investigação, uma vez que não é possível ainda estabelecer uma "biografia intelectual" de Telles, que seja capaz de ilustrar seu percurso de projetista para arquiteto, e de indicar claramente suas possíveis influências projetuais e filiações a correntes do pensamento arquitetônico.

Por outro lado, os relatos e documentos levantados, permitiram a elaboração de uma biografia de Telles com especial interesse na sua trajetória profissional, sistematizada em uma linha do tempo que procura estabelecer paralelos entre sua vida e obra (FIGURA 3).

Cabe apontar que a biografia é uma narrativa da trajetória de determinado indivíduo, buscando interpretá-lo por meio dos acontecimentos que lhe marcaram a vida sempre com uma finalidade específica seja ela conhecer, questionar, explorar, entre outras (CARINO, 1999). No caso de trajetórias em que existe produção artística e cultural, como a arquitetura por exemplo, a articulação entre a produção e a história do autor podem indicar possíveis trocas entre elas, esclarecendo aspectos relevantes de ambas. Assim, respostas a diversas indagações podem se apresentar ao longo do texto biográfico. Além disso, destaca-se que tal trajetória deve ser interpretada em relação ao seu contexto, que, de algum modo, contribui para sua construção. A biografia pode assim, também auxiliar a revelar aspectos de determinado momento, atuando como fonte historiográfica. 
No caso da biografia de Telles a finalidade é conhecer sua história para buscar meios de compreender sua obra. Explorar a biografia deste arquiteto que produziu durante um importante momento da história de Cataguases, pode contribuir com possíveis esclarecimentos acerca de sua obra e, ao mesmo tempo, ampliar noções sobre o momento histórico arquitetônico da cidade em si.

Figura 3 - Linha do tempo que relaciona aspectos biográficos e a trajetória profissional de Luzimar Telles, com destaque das duas principais cidades onde atuou: Rio de Janeiro (em verde) e Cataguases (em azul)

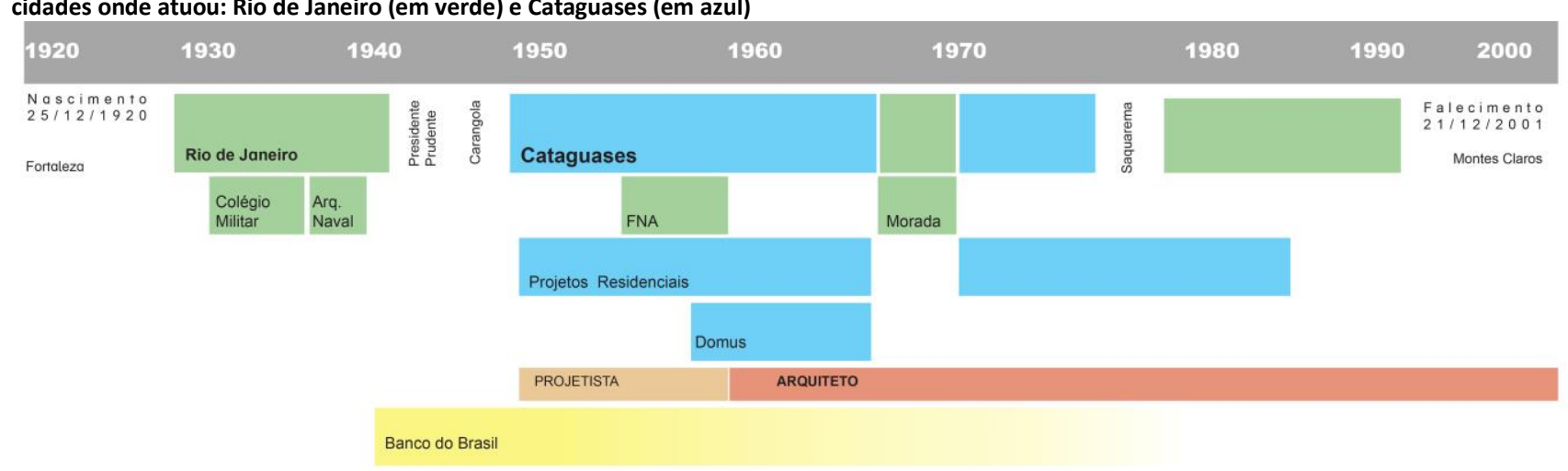

Fonte: os autores.

\section{Telles projetista e suas primeiras obras: traçando alguns paralelos}

Luzimar Natalino Cerqueira de Góes Telles nasceu no dia de natal de 1920, em Fortaleza, Ceará. Mudou-se ainda criança para a cidade do Rio de Janeiro, onde viveu com a mãe, após o desquite dos pais. Passou a infância e juventude nesta cidade, até começar a trabalhar no Banco do Brasil, quando mudanças de cidade se tornaram frequentes na sua vida, até chegar em Cataguases em 1949. Foi nesta cidade que se radicou e, entre idas e vindas, produziu a maior parte de sua obra arquitetônica. Telles foi casado por duas vezes, e teve seis filhos. Cursou arquitetura na FNA entre 1955 e 1560. Dedicou pelo menos trinta e seis anos de sua vida a construção civil, trinta e um deles oficialmente como arquiteto. Trabalhou até quando a saúde lhe permitiu, mesmo quando desenvolveu Mal de Parkinson, em meados da década de 1980. No dia 18 de dezembro de 2001, faleceu aos 81 anos na cidade de Montes Claros, Minas Gerais.

Sua formação escolar passou pelo Colégio Militar do Rio de Janeiro, entre 1933 e 1938. Documentos localizados no NPD da FAU-UFRJ indicaram que ao longo dos quatro primeiros anos deste curso teve contato com a disciplina de "Desenho", obtendo sempre boas notas, estando, inclusive, entre as maiores de todo seu histórico. Após concluir o Colégio, Luzimar Telles ingressou em um curso de "Projeto de Arquitetura Naval" da Marinha Brasileira, no Rio de Janeiro. Ainda que não se tenha informações precisas acerca deste curso, acredita-se que tenham desenvolvido suas habilidades como desenhista e também fundamentos do ato de projetar.

Diante disso, pode-se supor que Telles, desde cedo, apresentava interesse e, até mesmo, certa aptidão para a representação gráfica, importante aspecto da futura profissão. As entrevistas apontaram que o arquiteto tinha o constante hábito de desenhar. Mencionou-se também que sua "habilidade" com o desenho era essencialmente com a representação técnica, ao contrário de sua primeira esposa, que era artista plástica. Tal fato pode ser justificado por sua educação prévia: técnica e militar. Esta relação com desenho, em especial o desenho projetivo, como era denominado o que se chama hoje desenho técnico, pode justificar o conhecimento que Telles possuía no início de sua atuação em Cataguases, quando desenvolveu projetos arquitetônicos antes mesmo de iniciar sua graduação em arquitetura. 
Após concluir o curso da Marinha, ainda morando no Rio de Janeiro, Telles foi indicado para o cargo de Fiscal da Carteira Agrícola do Banco do Brasil, cuja função consistia em visitar e fiscalizar propriedades rurais que recebiam financiamentos do banco. No cargo, foi transferido para diferentes cidades como Presidente Prudente-SP e Carangola-MG, até por fim, Cataguases.

O momento da chegada de Telles a Cataguases praticamente coincide com o auge da produção de arquitetura moderna na cidade. Segundo Alonso (2010) tal momento se deu em 1948, com diversas construções modernas em andamento, inclusive dos arquitetos de maior destaque. Neste sentido, a efervescência da produção de arquitetura moderna local, somada ao conhecimento em desenho que possuía, podem ter oferecido as condições para que optasse por também atuar neste campo.

Assim, aos 30 anos de idade, Telles passou a trabalhar como "projetista" em Cataguases, primeiramente, ao que tudo indica, desenvolvendo projetos residenciais para outros funcionários do Banco do Brasil local. Além disso, destaca-se que o cargo de fiscal permitia flexibilidade de horários de trabalho, o que aparentemente, possibilitou que conciliasse as atividades do banco com o desenvolvimento dos projetos.

O projeto mais antigo de Telles, datado de 1950, é uma pequena residência, cujo proprietário e endereço não puderam ser confirmados em função de danos no documento (FIGURA 4 acima à esquerda). Podem ser observadas características que remetem mais a uma linguagem neocolonial que ao moderno que o destacaria posteriormente. Dois anos depois, projetou as residências de Naudir Machado, recentemente demolida, e Altamiro Peixoto localizada na atual Av. Humberto Mauro, uma das vias mais importantes da cidade, predominantemente ocupada naquele momento pela classe mais abastada. Nesta mesma avenida Telles projetou diversas outras residências, como por exemplo, para José Queiroz Filho em 1953 (FIGURA 4 acima à direita), Mauro Carvalho Ramos em 1955 (FIGURA 4 abaixo à esquerda), e Eudaldo Lessa na década de 1960 (FIGURA 4 abaixo à direita). Todas estas apresentam planos inclinados em suas elevações frontais. Todas, com exceção da primeira residência, apresentam telhados escondidos atrás de platibandas, elementos vazados, jardins frontais, garagem no mesmo volume da edificação e algumas formas geométricas marcantes. Estas são algumas das características presentes também em diversos outros exemplares da arquitetura modernista produzida em Cataguases.

Entretanto, é perceptível, já neste momento, que as residências de Telles apresentam soluções predominantemente restritas a planos, sejam verticais (elevações) ou ainda horizontais (plantas), como se o arquiteto desenvolvesse o projeto apenas em planta baixa, e não a partir de um raciocínio volumétrico-espacial. Ao observar a representação em corte dos projetos, não se nota nenhuma relação vertical de continuidade espacial, como pé direito duplo ou níveis intermediários entre pavimentos por exemplo, como figura nos exemplares modernos locais dos arquitetos renomados. Este aspecto, observado ao longo de sua trajetória, parece confirmar a leitura de Mello (2014) de que as casas de Telles seriam mais "simples" que as dos arquitetos de maior renome que atuaram na cidade.

Nota-se também neste período inicial, que os projetos de Telles apresentavam afinidades, ao menos na aparência, com a sintaxe proposta pela arquitetura moderna. Indaga-se a respeito do salto de maturidade projetual percebido entre a residência de 1950, e as produzidas nos anos seguintes. Esta mudança se justificaria pelas possíveis exigências dos clientes ou pelas verbas disponíveis? Quais seriam as referências de Telles neste período? 
Figura 4 - Projetos de Luzimar Telles: primeiro projeto localizado (acervo do DEMPHAC), de 1950 (à esquerda acima) e as residências de José Q. Filho, 1953 (à direita acima); de Mauro C. Ramos, 1953 (à esquerda abaixo); e de Eudaldo Lessa, década de 1960 (à direita abaixo)
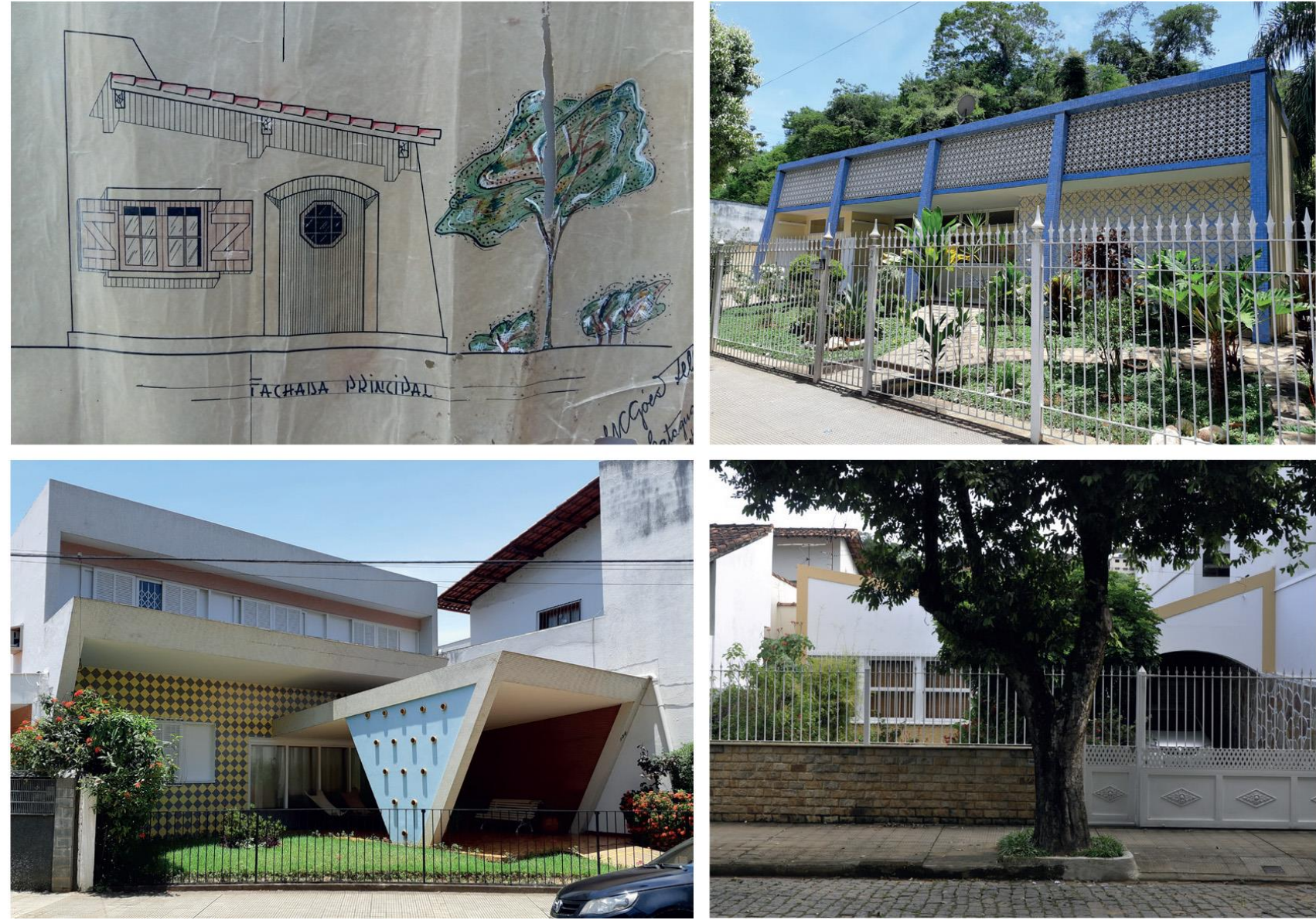

Fonte: os autores.

As entrevistas apontaram, neste momento de sua carreira, sua primeira esposa como uma grande incentivadora. Talvez possa-se afirmar que, até certo ponto, o talento artístico da esposa o tenha ajudado nas primeiras concepções. Talvez Telles possa ser considerado como como um autodidata, tal qual Artur Arcuri (1913-2010), engenheiro de formação que atuou como arquiteto na cidade de Juiz Fora-MG, próxima a Cataguases. Uma outra possibilidade, que não descarta as anteriores, seria a relação com as próprias residências locais produzidas pelos arquitetos renomados. Corrobora esta possibilidade a perceptível proximidade formal entre a residência de Francisco Inácio Peixoto, de autoria de Oscar Niemeyer na cidade (1941) (FIGURA 5 à esquerda), e a de Altamiro Peixoto (1952), projetada por Telles (FIGURA 5 à direita). Pode-se perceber o emprego de elementos que remetem a arquitetura colonial brasileira como as janelas em azul sobre o volume branco, o uso de telhas cerâmicas em duas águas no sentido longitudinal, e a solução em dois pavimentos, com as aberturas dos quartos voltados para a rua.

Até a metade da década de 1950, Telles desenvolveu diversos outros projetos residenciais em Cataguases, apresentando uma linguagem formal de caráter moderno, existente em diversas edificações na cidade. Neste período assinou os próprios projetos apresentando o "registro precário" de $\mathrm{n}^{\circ} 1.114$ - $4^{\mathrm{a}}$ Região, junto ao Conselho Regional de Engenharia, Arquitetura e Agronomia (CREA) 5 .

Destaca-se ainda que muitos projetos que desenvolveu neste período inicial, como projetista, figuram entre os mais recorrentes nas publicações mencionadas anteriormente. Mesmo assim, Telles decidiu cursar uma faculdade de arquitetura. 


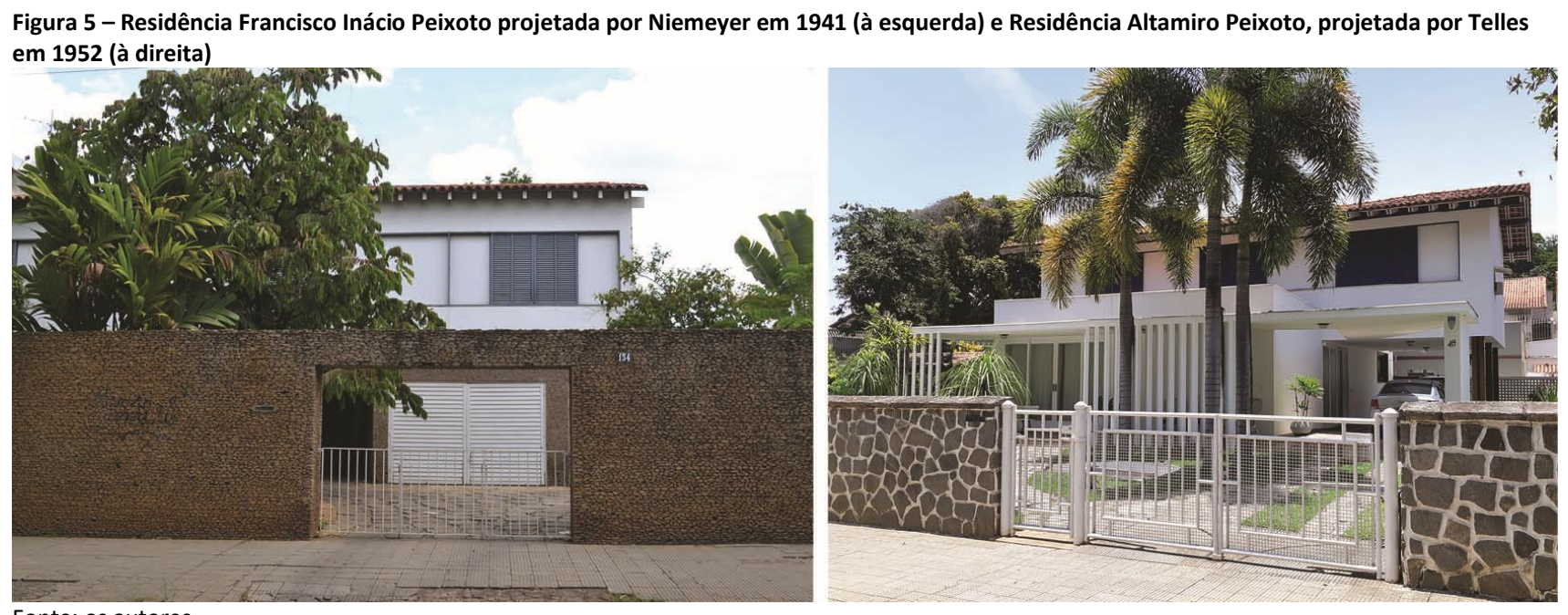

\section{Telles arquiteto e obras posteriores}

Cinco anos após seu primeiro projeto em Cataguases, Telles ingressou na FNA, uma das maiores e mais importantes faculdades da época, onde formaram-se também arquitetos como Oscar Niemeyer (1934), Aldary Toledo (1940), Francisco Bolonha (1945), e os irmãos Marcelo, Milton e Maurício Roberto (1930, 1934 e 1944 respectivamente).

A motivação para Telles obter diploma de arquiteto é geralmente atribuída ao contexto local de agitação cultural. Ainda que não seja possível negar tal fato, aparentemente, a decisão de cursar uma faculdade de arquitetura surgiu quando Ottônio Alvim, amigo de Telles, deixou de contratá-lo para projetar sua residência porque não era um arquiteto diplomado. O projeto ficou a cargo de Francisco Bolonha, tendo início em 1954 (ALONSO, 2009). Data que coincide com o início do curso de Telles e dá suporte a esta consideração, que foi mencionada em uma das entrevistas realizadas durante o desenvolvimento da pesquisa ${ }^{6}$.

Telles continuou a morar e trabalhar em Cataguases durante os anos que cursou a faculdade (1955-1960), viajando constantemente para o Rio de Janeiro. Neste mesmo período, ainda que pareça uma demanda complicada, continuou com suas atividades de funcionário do Banco do Brasil, atuou como projetista e construtor, e foi também "sócio orientador" da loja de móveis e decoração Domus, como sugere um documento localizado no acervo do NPD (FAU-UFRJ). Apesar dos muitos compromissos, Telles cursou as vinte e seis disciplinas do curso, ao longo de cinco anos. Suas melhores notas foram em disciplinas mais práticas como "Composições de Arquitetura", "Perspectivas - Sombras" e "Organização do Trabalho", enquanto outras como "História da Arte", "Legislação - Economia e Política" e ainda "Arquitetura no Brasil", de cunho mais teóricas, figuram entre as de média mais baixa (FIGURA 6). Tal fato pode ser atribuído a sua formação prévia, a habilidade em desenho técnico, e também a sua experiência profissional tanto "na prancheta" quanto nos canteiros de obras. 


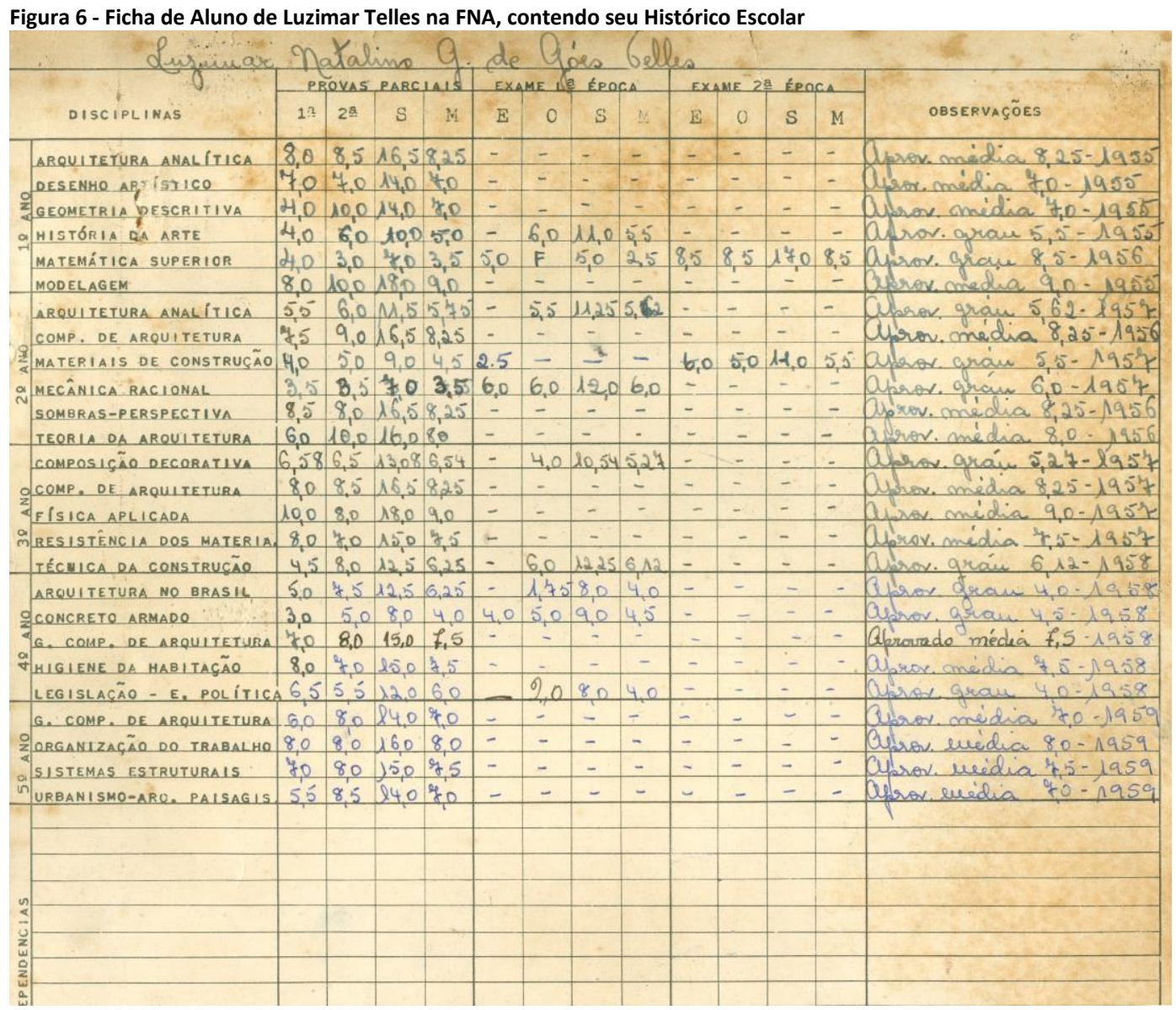

Fonte: Acervo NPD da FAU - UFRJ, cedido aos autores.

Dois dias após colar grau na FNA, Telles, agora arquiteto, providenciou seu registro definitivo junto ao CREA/RJ. Assim, a partir de 1960, passou a figurar em seus projetos o registro definitivo $n^{\circ} 10.158-5^{a}$ Região. Tal fato, juntamente com sua filiação ao Instituto de Arquitetos do Brasil (IAB) em 1955, ainda quando era recém iniciado no curso de arquitetura, parece reforçar seu aparente desejo de se identificar oficialmente como arquiteto. Tal desejo parece responder ao que se supõem ter sido sua motivação para realizar o curso, e justifica-se também pelo fato de que naquele momento, seria o único arquiteto diplomado residente, efetivamente, em Cataguases.

Em 1958, ainda estudante, projetou sua primeira residência própria, em terreno de pequenas dimensões e formato irregular, novamente na Av. Humberto Mauro (Figura 7 à esquerda acima, identificada nos arquivos com o nome de sua esposa na época). Talvez seu projeto de maior destaque e reconhecimento local, pelo volume destacado, presença de pilotis e fachada em cobogós. Já como arquiteto, na primeira metade da década de 1960, Telles desenvolveu, cerca de vinte e seis projetos, entre eles habitações operárias e casas geminadas, além de residências particulares para Hélio Lourenço (Figura 7 à direita acima) em 1960 (hoje descaracterizada), Lício Lacerda em 1961, e residências com consultório médico para Jayme Afonso Cruz (Figura 7 à esquerda abaixo) e Antônio Hélcio Pereira Queiroz (Figura 7 à direita abaixo), ambas de 1964 e de significativa distinção local.

São casas que apresentam características formais modernas, em especial os volumes prismáticos, a composição a partir de planos e formas simples, aberturas generosas, balanços, uso de materiais diversos como pastilhas, pedras e cerâmicas. Telles explorou soluções racionais para lotes bastante distintos, sem abrir mão da linguagem formal 
empregada pelos modernos renomados. Tanto que, não raras vezes, turistas e cidadãos locais atribuem suas obras a arquitetos de maior renome.

Figura 7 - Quatro projetos residenciais de Telles: Anamirtes Lacerda,1958 (à esquerda acima), Hélio Lourenço, 1960, descaracterizada (à direita acima); Jayme Afonso de Souza, 1964 (à esquerda abaixo) e Antônio Hélcio P. Queiroz, 1964 (à direita abaixo)
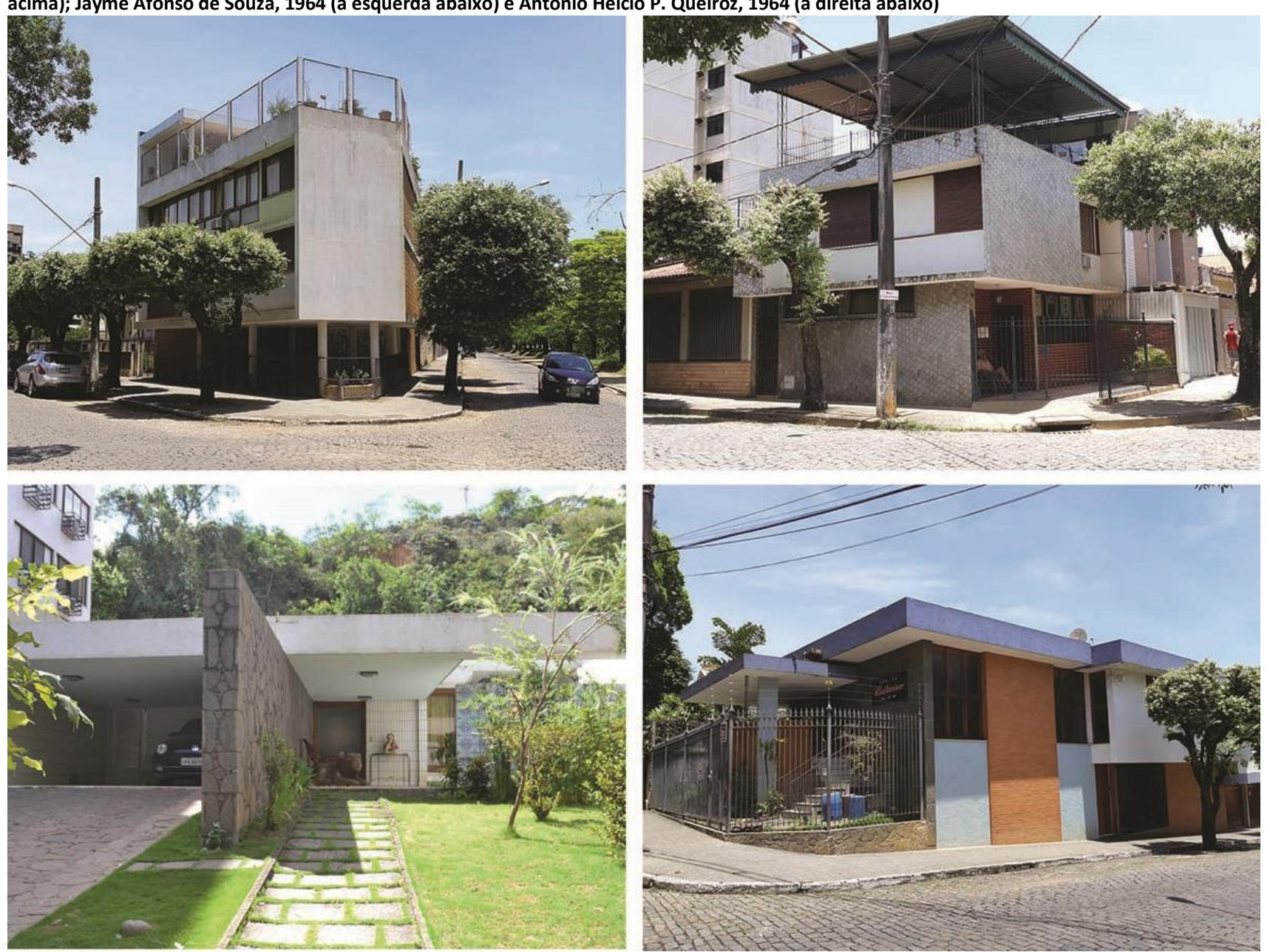

Nota: Anamirtes Lacerda é a segunda esposa de Telles. Fonte: os autores.

Após 1964 Telles ficou quatro anos sem projetar em Cataguases por ter se mudado, com a família, novamente para a cidade do Rio de Janeiro. Diversas explicações para esta mudança foram apontadas nas entrevistas: nova transferência pelo banco, desejo de investir no design de seus móveis e levá-los para um mercado maior, apenas uma escolha pessoal e, por fim, as entrevistas mencionaram embates políticos locais, repercussões do contexto nacional do golpe de 1964, provavelmente em função da formação militar de Telles.

O arquiteto voltou a atuar na cidade em 1968, mesmo ainda morando na capital carioca. Em 1970, com 50 anos, retornou para Cataguases por influência de amigos. Segundo um de seus filhos, foi neste período que se aposentou do banco e fez questão de fazê-lo como arquiteto, ainda que assim recebesse um salário de valor menor.

Nos anos seguintes a produção de projetos cresceu e Telles desenvolveu residências como as de José Inácio Peixoto (1973), Manoel Barbosa Ladeira (1975) (FIGURA 8 à esquerda acima), Oigres Segall (1975) (FIGURA 8 à direita acima), Paulo Sérgio Ferreira de Souza, 1975 (FIGURA 8 à esquerda abaixo), Delson Bianchi (1976), Jayme A. C. de Souza (1977), todas inseridas ou nas proximidades da região protegida pelo IPHAN. Além destes exemplares destinados a clientes abastados, o arquiteto projetou também 
três modelos de "casas populares" para a Prefeitura Municipal em 1974, que seriam construídas em diferentes bairros. Estas últimas apresentam, em projeto, certa proximidade de soluções formais as demais casas projetadas no período, como o uso de telhados tradicionais em duas águas.

Figura 8 - Residências projetadas por Telles: Manoel Barbosa Ladeira, 1975 (à esquerda acima), Oigres Segall, 1975 (à direita acima); Paulo Sérgio Ferreira de Souza, 1975 (à esquerda abaixo), José Maria Porto Rocha, 1986 (à direita abaixo)
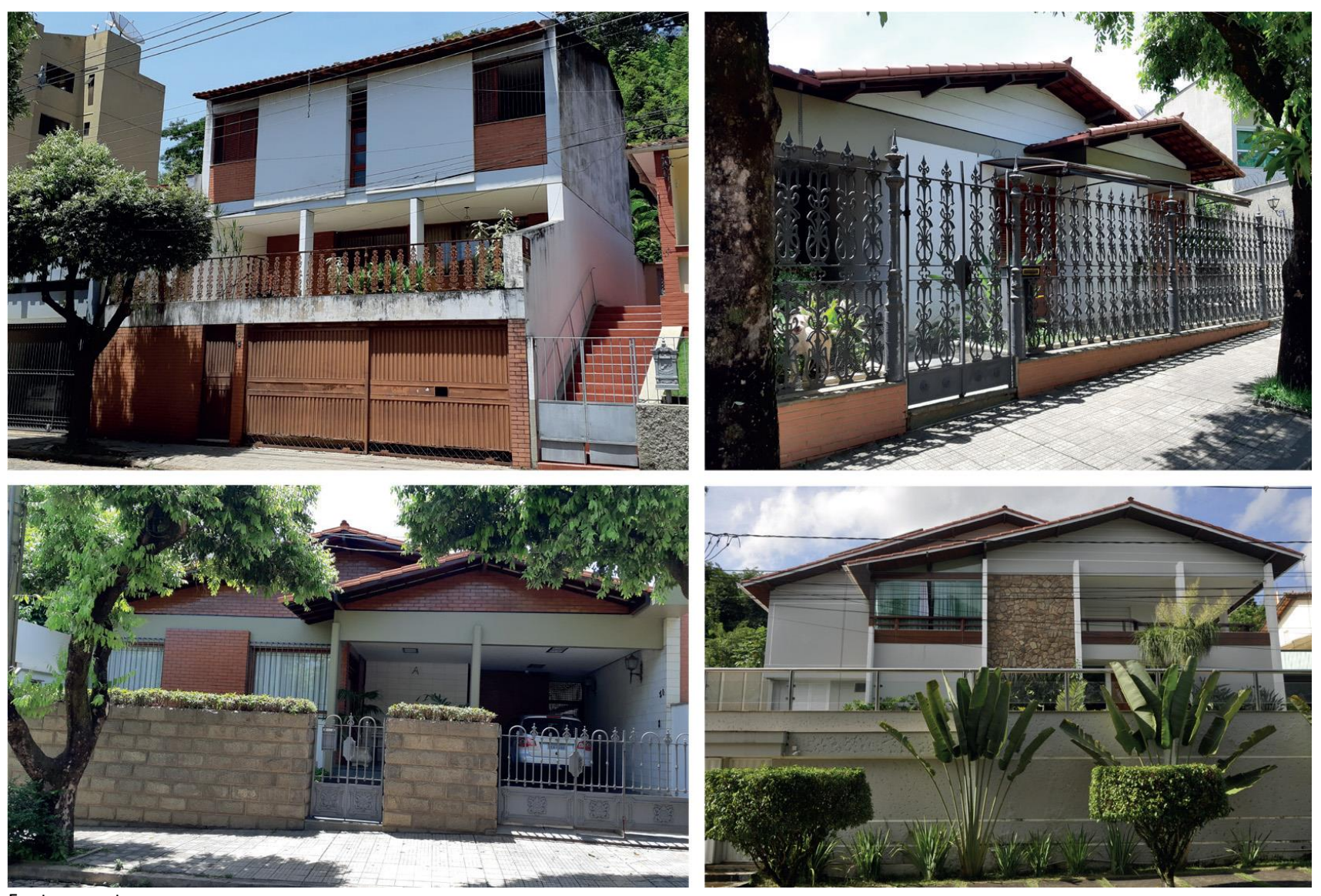

Fonte: os autores.

Estes últimos exemplos diferenciam-se daqueles projetos até 1964 por se mostrarem formalmente distantes da linguagem moderna empregada anteriormente, em que se percebem soluções formais mais variadas. A partir deste retorno a Cataguases, o arquiteto desenvolveu projetos que, em geral, caracterizam-se pelo emprego de uma gama mais restrita de materiais de acabamento externo e, principalmente, pela presença de telhados tradicionais (FIGURA 9). As soluções passam a apresentar maior proximidade formal, mesmo em terrenos distintos. O que poderia fundamentar tal variação nos procedimentos projetuais?

Pode-se tratar de um reflexo do cenário nacional em que mudanças vinham se desenhando, desde a década de 1950, mas eram abafadas pela dominante "escola carioca", aceita e identificada como sinônimo de arquitetura brasileira, praticamente sem contestatação à época (ZEIN; BASTOS, 2015).

A inauguração de Brasília em 1960, mesmo ano em que Telles se formou, é tida como auge do modernismo nacional e também ponto de mudança deste. A partir deste momento observa-se o crescimento de propostas que não se limitam às soluções até então dominantes. Não se tratou, no entanto do fim ou substituição de uma arquitetura por outra, como esclarecem Zein e Bastos: “(...) a arquitetura brasileira não acabou, nem 
perdeu seu rumo. Apenas mudou, como não poderia deixar de ser, transitando para outros paradigmas (...)" (ZEIN; BASTOS, 2015, p. 52).

Figura 9 - Redesenho das fachadas de algumas residências projetadas por Telles e exploradas na pesquisa do Mestrado, em ordem cronológica
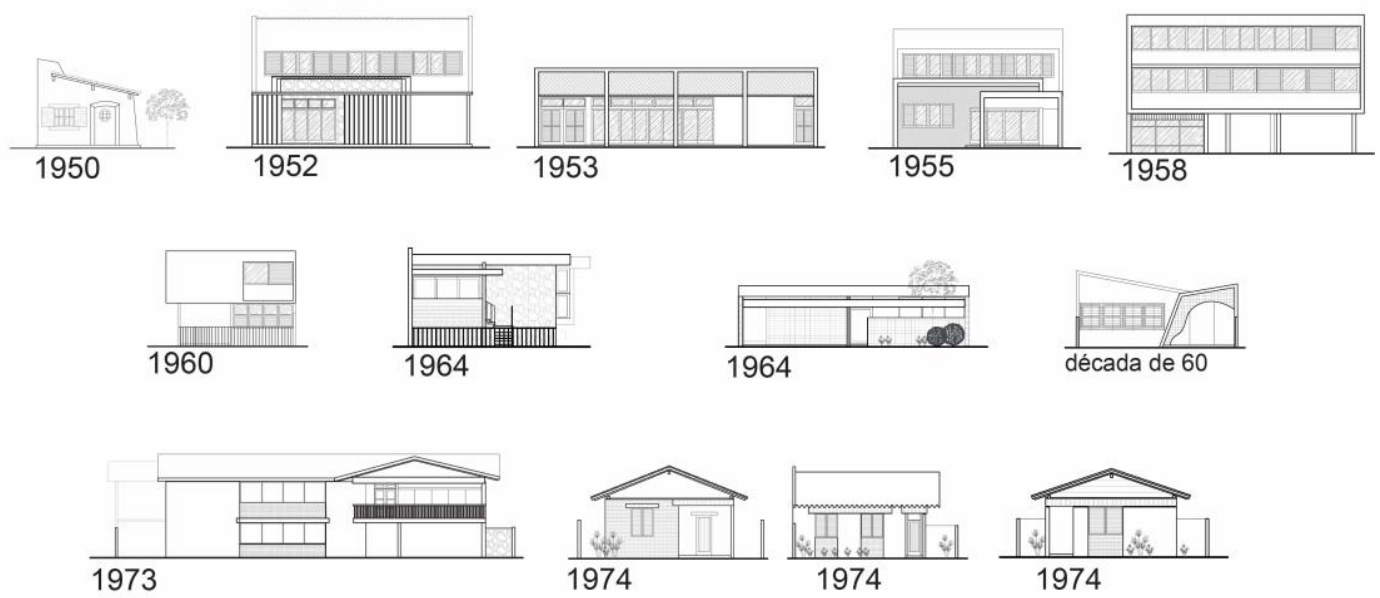

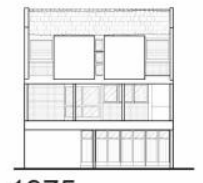

1975

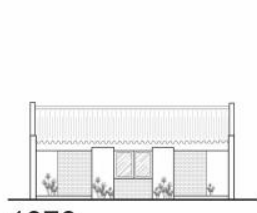

1976
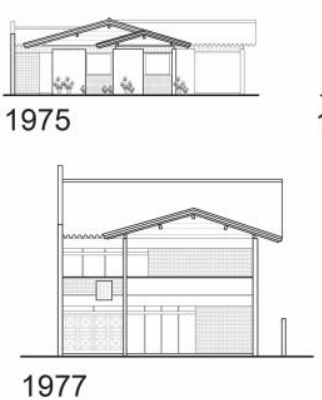

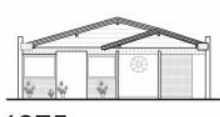

1975

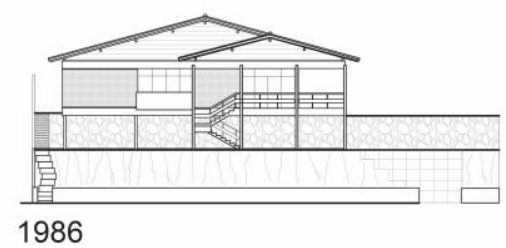

Fonte: os autores.

Ainda que sem uma sistematização crítica precisa, a literatura daquele momento, de modo geral, abordou tal mudança de paradigmas como um desvio dos cânones verdadeiros da arquitetura modernista e, “(...) é possivelmente uma das razões pela qual a arquitetura realizada naquelas décadas [1960 e 1970] está ausente da maioria dos manuais de arquitetura recentes, no Brasil como em toda parte" (ZEIN; BASTOS, 2015, p. 54).

Este aspecto parece encontrar eco também em Cataguases. Na cidade, a "escola carioca" esteve presente em quase totalidade das obras modernistas reconhecidas, e os projetos residenciais de Telles produzidos neste momento tardio são, em geral, omitidos das publicações. Ao se destacar apenas os primeiros projetos do arquiteto, aqueles mais próximos a linguagem dos arquitetos cariocas renomados, pode ser um esforço, ainda que não intencional, de reafirmar o conjunto local com uma arquitetura moderna tida como autenticamente moderna.

Ou ainda, as mudanças observadas na produção tardia do arquiteto poderiam ser atribuídas somente a uma escolha pessoal do próprio Telles, ou mesmo a sociedade local, agora desinteressada por modelos anteriormente adotados pela burguesia, coincididamente também não mais dominantes nacionalmente. Outra possível justificativa seria a mera adequação dos projetos às condições locais. O telhado tradicional por exemplo, configuraria uma solução mais ajustada ao clima quente de Cataguases, além de provavelmente apresentar menores custos dada a maior facilidade de execução por uma mão de obra disponível e não tão especializada. 
Seja qual for a justificativa, as mudanças na trajetória de Telles, ao mesmo tempo em que destacam diferentes aspectos de sua obra, levantam novas indagações. Pode-se questionar, por exemplo, se tais mudanças se limitam às soluções arquitetônicas ou incidem também nos modos como projetava. Estariam de algum modo relacionadas às lições aprendidas na FNA?

Produzindo esta arquitetura mais anônima, sem o vínculo aparente com a corrente que colocou Cataguases no mapa da arquitetura moderna brasileira, Telles permaneceu na cidade até 1977, quando se mudou para Saquarema, onde projetou cerca de dez residências, segundo entrevistas. Dois anos depois, muda-se novamente para o Rio de Janeiro, desta vez para supervisionar obras do Banco do Brasil junto a Construtora Caparaó, também responsável por executar construções em Cataguases, dentre elas a do hospital local.

Telles não voltou a residir em Cataguases, embora seus últimos projetos registrados na cidade tenham sido as residências para Hélio de Almeida (1984) e José Maria Porto Rocha (1986) (FIGURA 8 à direita abaixo).

\section{Telles: designer de móveis}

Entre 1958 e 1965 Telles foi sócio proprietário da loja "Domus - Arquitetura de Interiores" localizada em uma sala comercial do Cine Teatro Cataguases (1946-1952) projetado por Aldary Toledo e Carlos Leão (FIGURA 10). A Domus vendia móveis de alto padrão, feitos em madeira jacarandá, que o próprio arquiteto projetava e produzia. Vendeu também objetos de arte e decoração e funcionou como galeria de arte, promovendo exposições de artistas plásticos. Apesar de ter se mantido por alguns anos, a loja não se mostrou economicamente viável, provavelmente em função da limitada clientela para tal padrão em Cataguases. Ainda assim, Telles por vezes parece ter incluído mobiliário de sua autoria em alguns de seus projetos arquitetônicos.

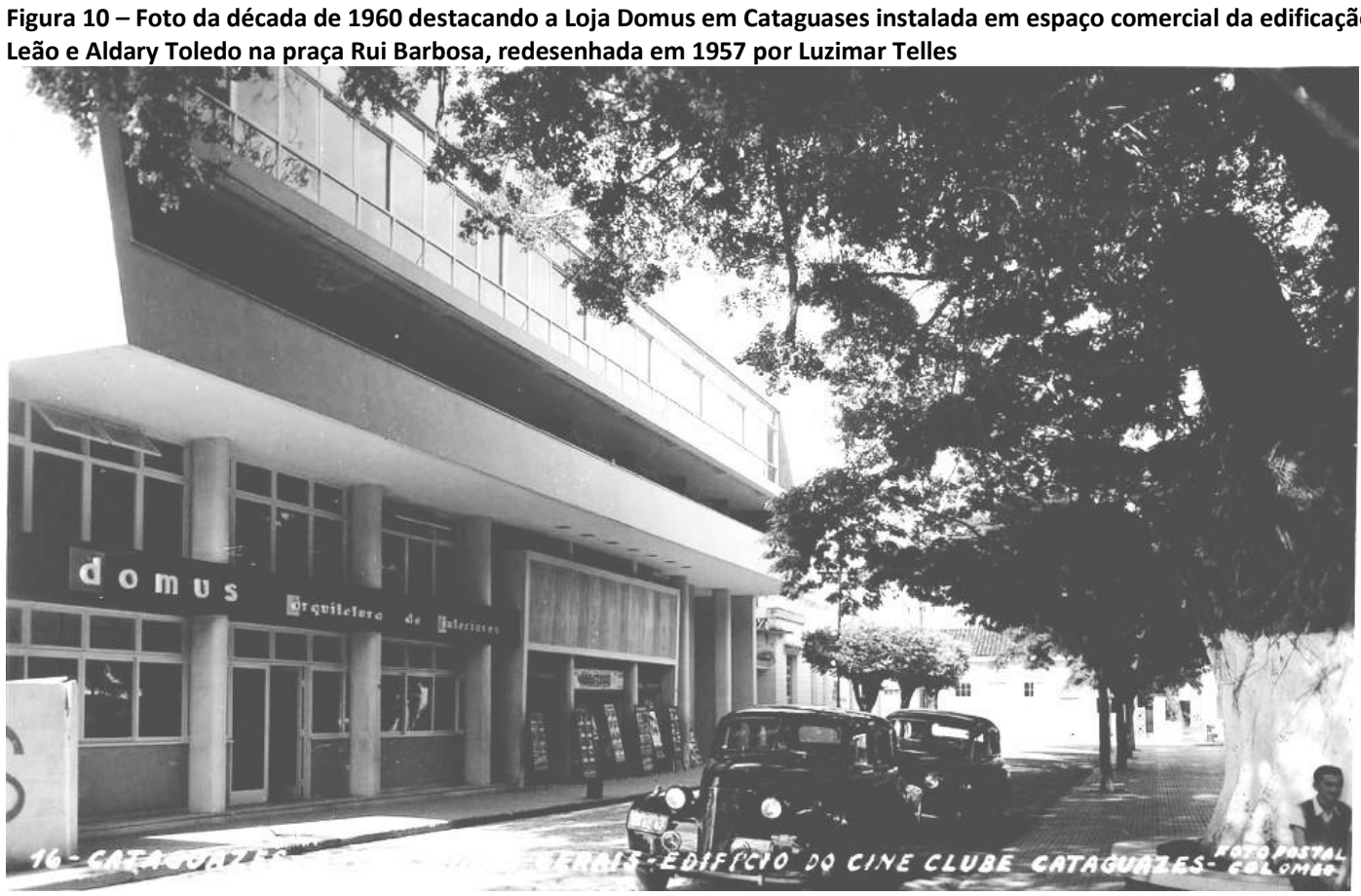

Fonte: Acervo do DEMPHAC, cedida aos autores.

Quando se mudou para o Rio de Janeiro em 1965, Telles insistiu na produção de mobiliário, e abriu a loja "Morada - Móveis e Objetos de Arte Ltda" no bairro Leblon. A 
Morada, tal qual a Domus, promoveu exposições de arte e comercializou móveis projetados pelo arquiteto, além de outros objetos de arte. Funcionou entre 1965 e 1970 quando fechou as portas por não apresentar retorno financeiro. Segundo um dos filhos de Telles, que trabalhou com o pai, apesar do potencial criativo e empenho produtivo, Telles tinha dificuldades para administrar o negócio por ser extremamente exigente e detalhista com os móveis que produzia. Apesar disso, apontou ainda que o mobiliário da Morada obteve certo reconhecimento. No ano de 1970, o governo brasileiro doou móveis para os escritórios da União Internacional dos Arquitetos (UIA) em Paris, entre eles alguns assinados por Telles. O mesmo filho relatou que foi a França, no lugar do pai, para acompanhar e realizar a montagem dos móveis, que por algum motivo, nunca chegaram. Este curioso fato permanece sem maiores esclarecimentos. Meses depois deste episódio, Telles retornou a Cataguases e a loja Morada também encerrou suas atividades.

Tal produção de móveis indica que Telles projetou em diferentes escalas, e que pode ter desenvolvido projeto completos, considerando a arquitetura e o mobiliário, tal qual destacados arquitetos modernistas. Tal fato, que sustentaria um estudo específico, poderia aproximar Telles destes arquitetos, revelar outros nuances de sua trajetória e apontar a relevância da produção deste mobiliário para Cataguases.

\section{Considerações finais}

Luzimar Telles é recorrentemente mencionado como o arquiteto com maior número de projetos modernos em Cataguases, ainda que parte considerável destes projetos e de sua trajetória profissional se encontrasse desconhecida e inexplorada. Esta pesquisa revelou que Telles projetou em Cataguases mais de cem residências (sem mencionar os projetos que realizou para outros programas), em cerca de trinta e seis anos de atuação, primeiro como projetista, depois como arquiteto. Esclareceu que o arquiteto desenvolveu projetos residenciais diversos, atendendo a clientes de classes socioeconômicas diferentes e ainda projetou e produziu móveis de alto padrão, além de promover exposições de arte. Destacou, particularmente, o distanciamento, após a década de 1970, da linguagem modernista usada nas suas primeiras obras em Cataguases. Estes aspectos parecem acrescentar maior complexidade a sua trajetória e demandam maiores investigações.

Neste primeiro estudo específico acerca de Luzimar Telles foi possível conhecer de forma mais profunda sua trajetória profissional, elucidar, em especial, aspectos de sua formação acadêmica e atuação profissional, através do exame dos projetos residenciais unifamiliares desenvolvidos em Cataguases. Os documentos levantados indicaram que desde a juventude Telles apresentou uma relação de familiaridade com o desenho, principalmente de caráter técnico. O que confirma as menções a uma visão essencialmente prática e objetiva da arquitetura relatadas nas entrevistas.

Outro aspecto a ser destacado na biografia de Luzimar Telles refere-se a sua dupla atividade de trabalho. Primeiramente, foi o trabalho no banco que o levou a Cataguases e, depois possibilitou que estabelecesse os contatos sociais que resultaram nas encomendas dos projetos das primeiras residências, ainda como projetista. Além disso, a mencionada flexibilidade de horários parece ter sido de grande valia para a sua atuação e formação como arquiteto, antes e depois do ser diplomado. Por outro lado, observar este acúmulo de funções levanta questionamentos como: por que permaneceu como funcionário do banco com tamanha demanda de projetos na cidade? Seria a arquitetura para Luzimar Telles uma atividade secundária? Ainda que não seja possível afirmar, o empenho para obter o diploma e a quantidade de projetos desenvolvidos parece apontar para a profissão de arquiteto como um trabalho principal, 
talvez associado a própria realização pessoal. A atividade de bancário apenas garantiu uma estabilidade financeira, que possibilitou, inclusive, sua incursão também no campo do design?

Esta pesquisa contribuiu para sistematizar e registrar o material gráfico da produção residencial de Luzimar Telles em Cataguases que podem ser usadas como referência para outros estudos. E, principalmente, iniciou uma discussão mais fundamentada acerca da trajetória e da arquitetura produzida por Telles.

Como uma primeira abordagem específica sobre vida e obra desse arquiteto, a pesquisa apresenta limitações e não esgota a exploração da obra Telles. Informações sobre alguns projetos residenciais ainda podem ser coletadas, e, mais ainda, as obras não residenciais do arquiteto permanecem aguardando investigações mais acuradas. Ainda assim, acredita-se ter reduzido uma significativa lacuna no contexto dos estudos da arquitetura de Cataguases, e por meio da sistematização dos dados levantados, estabeleceu-se uma referência que pode contribuir para explorações da obra de Telles não apenas historiográficas, mas também analíticas.

Investigar e explorar a atuação de Telles em Cataguases significa ampliar o conhecimento acerca do patrimônio moderno da cidade, aprofundando a discussão do legado da cidade e o papel dos projetos do arquiteto dentro deste contexto. Assim, este olhar inicial permitiu inferir possíveis respostas para perguntas como: seriam as residências de Telles significativas dentro do contexto local permeado por exemplares modernos tão caros a historiografia desse movimento no Brasil? Por tudo que foi apresentado, inclusive a trajetória bastante particular de Telles, suas obras apresentam, de fato, grande relevância a nível local? Seriam estas residências apenas reproduções da linguagem moderna criada pelos "arquitetos ilustres" ou podem ser consideradas explorações com características próprias?

Observou-se, durante a pesquisa, que a espacialidade das casas de Telles é praticamente restrita aos planos, principalmente horizontal, como se solucionasse o projeto pela planta baixa, sem estabelecer continuidades espaciais ou relações volumétricoespaciais significativas. Desse modo, podem ser consideradas, sem exceção, como mais elementares que aquelas projetadas em Cataguases pelos arquitetos cariocas.

A produção da fase inicial do arquiteto não parece ser mera reprodução sem consciência da linguagem moderna dada a variedade das soluções formais, principalmente, considerando como se deu a sua formação. Por outro lado, ainda parece precipitado apontar aspectos singulares em sua obra.

Ao afastar-se da linguagem moderna, de certo modo, mostrou não se limitar a ela. Assim, parece haver um descompasso entre o "modernismo" produzido por Telles e o dos outros arquitetos, mas esta medida ainda está a ser estabelecida, através de maiores explorações e reflexões.

Por fim, a pesquisa aponta que a arquitetura de Telles se expande para além do período histórico em que Cataguases reconhecidamente destacada. Trata-se justamente do período em que historiografia da arquitetura nacional ainda carece de maiores explorações e investigações, principalmente a partir de meados da década de 1960. Considerar a produção arquitetônica de um nome pouco conhecido, situada em uma cidade do interior, pode parecer insignificante aos desavisados, mas é sempre necessário e pertinente dar luz ao mar de caminhos que a historiografia da arquitetura moderna ainda pode percorrer seja em âmbito nacional, ou mesmo, local. 


\section{Agradecimentos}

Agradecemos a família do arquiteto Luzimar Telles pela colaboração prestimosa aos funcionários dos acervos do Instituto Francisca de Souza Peixoto, DEMPHAC e NPD (FAU-UFRJ) pela atenção e tempo despendido; e as pessoas que indicaram e cederam projetos, fotos, endereços, relatos e documentos, com destaque, aos pesquisadores Paulo Alonso e Ulisses Lins que muito contribuíram com a pesquisa. O presente trabalho foi realizado com apoio da Coordenação de Aperfeiçoamento de Pessoal de Nível Superior - Brasil (CAPES), por meio de bolsa de mestrado.

\section{Notas}

(1) Instituto do Patrimônio Histórico e Artístico Nacional (IPHAN). Conjuntos Urbanos Tombados (Cidades Históricas). Disponível em: <http://portal.iphan.gov.br/pagina/ detalhes/123/>. Acesso em: 22 out. 2019.

(2) International Working Party for Documentation and Conservation of Buildings, Sites and Neighbourhoods of the Modern Movement (Comitê Internacional para a Documentação e Preservação de Edifícios, Sítios e Unidades de Vizinhanças do Movimento Moderno). Fundada em 1988 e, atualmente com representação em mais de quarenta países, figura como uma das mais importantes organizações não-governamentais mundiais ligadas a causa preservacionista. Tem como objetivo documentar e preservar as criações do Movimento Moderno na arquitetura, urbanismo e afins. Disponível em: < http://exhibition.docomomo.com/>. Acesso em: 26 jul. 2018

(3) Na segunda etapa dessa investigação, foram exploradas analiticamente vinte e oito projetos residenciais unifamiliares de Luzimar Telles em Cataguases, empregando de modo complementar as duas ferramentas metodológicas apontadas.

(4) São três os documentos que se constituíram listas parciais de projetos de Telles, e que continham, em geral, apenas informações relativas aos nomes dos clientes. Uma primeira lista foi localizada por Alonso (2010) nos arquivos do IPHAN, uma segunda foi coletada também por Alonso (2009), quando da elaboração do "Guia do patrimônio modernista de Cataguases", ambas com autoria e datas de elaboração desconhecidas. A terceira lista foi elaborada por uma filha de Telles, e foi gentilmente cedida aos pesquisadores.

(5) Este tipo de registro era fornecido a pessoas com reconhecido conhecimento na área de construção civil, e foi extinto pela Lei $\mathrm{N}^{\circ} 5.194$, de 24 dezembro de 1966.

(6) As entrevistas, no âmbito dessa pesquisa, foram realizadas seguindo os procedimentos aprovados pelo Comitê de Ética em Pesquisa com Seres Humanos da Universidade Federal de Viçosa (CEP/UFV).

\section{Referências}

ALONSO, Paulo Henrique (Coord. e Org.). Cataguases - arquitetura modernista: guia do patrimônio cultural. Cataguases: Instituto de Estudos do Desenvolvimento Sustentável, 2009.

ALONSO, Paulo Henrique. A construção de um patrimônio cultural: o tombamento federal de Cataguases, Minas Gerais. 200 f. Dissertação (Mestrado em Ambiente Construído e Patrimônio Sustentável) - Universidade Federal de Minas Gerais, Escola de Arquitetura, Belo Horizonte, 2010.

CARINO, Jonaedson. A biografia e sua instrumentalidade educativa. Educ. Soc., v. 20, n. 67, p. 153-182, 1999 DOI: https://doi.org/10.1590/S0101-73301999000200006.

CAVALCANTI, Lauro Augusto de Paiva. Quando o Brasil era moderno: guia da arquitetura 1928-1960. Rio de Janeiro: Aeroplano, 2001.

CLARK, Roger H; PAUSE, Michael. Precedents in architecture: analytic diagrams, formative ideas, and partis. New York: John Wiley \& Sons, 1985.

COUTO, Thiago Segall. Patrimônio modernista em Cataguases: razões de reconhecimento e o véu da crítica. Arquitextos, São Paulo, ano 05, n. 054.04, Vitruvius, nov. 2004. Disponível em: https://www.vitruvius.com.br/revistas/read/arquitextos/05.054/527. Acesso em: 20 out. 2019.

HILLIER, Bill; HANSON, Julienne. The social logic of space. Cambridge: Cambridge University Press, 1984. 
LINS, Ulisses V. Subsídios para o estudo da imagem urbana de Cataguases: a região da Praça da Estação. Dissertação (Mestrado em Ambiente Construído e Patrimônio Sustentável) - Escola de Arquitetura, Universidade Federal de Minas Gerais, Belo Horizonte, 2012.

MELLO, Fernando Antônio de Oliveira. Cataguases e suas modernidades. Tese (Doutorado em Arquitetura e Urbanismo) - Faculdade de Arquitetura e Urbanismo, Universidade de Brasília, Brasília, 2014.

MONTANER, Josep Maria. Arquitetura e crítica. 2. ed. São Paulo: Gustavo Gili, 2015.

XAVIER, Wescley Silva. O eterno legado modernista de Cataguases-MG no passadismo do círculo privilegiado da cultura. $300 \mathrm{f}$. Tese (Doutorado em Administração) - Faculdade de Administração, Universidade Federal de Minas Gerais, Belo Horizonte, 2013.

ZEIN, Ruth Verde; BASTOS, Alice Junqueira. Brasil: arquiteturas após 1950. São Paulo: Perspectiva, 2015.

\section{${ }^{1}$ Filipe Quaresma Poyares de Oliveira}

Arquiteto e Urbanista. Mestre em Arquitetura e Urbanismo pela Universidade Federal de Viçosa. Arquiteto associado no Estúdio Trilho e professor do Curso de Arquitetura e Urbanismo da Faculdades Integradas de Cataguases, Grupo Educacional Unis. Endereço postal: Av. João Inácio Peixoto, 188, Cataguases, MG, Brasil, 36773560.

\section{${ }^{2}$ Denise Mônaco dos Santos}

Arquiteta e Urbanista. Doutora em Arquitetura e Urbanismo pela Universidade de São Paulo. Professora Adjunta no Departamento de Arquitetura e Urbanismo da Universidade Federal de Viçosa. Endereço postal: Avenida Peter Henry Rolfs, s/n, Campus Universitário, Viçosa, MG, Brasil, 36570-900. 